\title{
GMR
}

Thesis Abstract

\section{Supplementation levels of exogenous alpha-amylase in broilers diets}

\author{
H.B. Oliveira, M.I.A. Silva and F.R. Mesquita \\ 2012. Universidade Federal de Lavras, Lavras, MG, Brasil \\ Msc thesis. Orienting Prof.: F.R. Mesquita \\ Corresponding author: H.B. Oliveira \\ E-mail: henrique_braga@cargill.com \\ Genet. Mol. Res. 16 (3): gmr16038766 \\ Received May 6, 2016 \\ Accepted May 30, 2016 \\ Published August 17, 2017 \\ DOI http://dx.doi.org/10.4238/gmr16038766 \\ Copyright (C) 2017 The Authors. This is an open-access article distributed under the terms of \\ the Creative Commons Attribution ShareAlike (CC BY-SA) 4.0 License.
}

This study aimed to evaluate the supplementation levels of an exogenous alphaamylase in broilers diets and compare two indicators in determining the diets energy. The experiment was divided into two parallel evaluations, being one of performance and the other of metabolism. In performance assay, 1,700 one-day-old Cobb-500 male chicks were used. The animals were distributed in 50 experimental plots and evaluated five treatments with ten replicates in a completely randomized design (CRD). The treatments were: a positive control (PC), a negative control (NC) and three alpha-amylase supplementation levels 200, 400 and $600 \mathrm{~g} / \mathrm{t}$, and the $\mathrm{NC}$ was formulated with 50 and $90 \mathrm{kcal}$ of energy reduction in relation to the $\mathrm{PC}$ to the phases from 1 to 21 days and from 22 to 42 days, respectively. In the metabolism assay were used 240 animals, 150 birds for stage from 14 to 21 days and 90 birds to stage from 35 to 42 days of age and the treatments were the same as the performance assay, with six replicates per treatment in CRD. All diets of metabolism test contained the digestibility indicators Lipe ${ }^{\circledR}$ (eucalyptus purified lignin) and chromic oxide $\left(\mathrm{Cr}_{2} \mathrm{O}_{3}\right)$, in concentrations of 0.05 and $1.0 \%$, respectively. In the period from 1 to 21 days old, no significant differences were observed in weight gain (WG) $(\mathrm{P}>0.05)$, however, feed intake (FI) was found higher by using 200 ppm of enzyme $(\mathrm{P}<0.05)$ and better feed conversion $(\mathrm{FC})$ with the $\mathrm{PC}(\mathrm{P}<0.05)$. From 22 to 42 days, no significant differences were observed on the WG $(\mathrm{P}>0.05)$, but were

Genetics and Molecular Research 16 (3): gmr16038766 
observed lower FI and better FC to $\mathrm{PC}$ treatment $(\mathrm{P}<0.05)$. In the period from 1 to 42 days of age, significant differences were also not observed on the WG $(\mathrm{P}>0.05)$, but there was lower FI and better FC for the PC treatment $(\mathrm{P}<0.05)$. The AMEn (apparent metabolizable energy corrected for nitrogen balance), determined using the total collection, reaffirmed the values calculated for the $\mathrm{PC}$ and $\mathrm{NC}$ with intermediate data obtained from the enzyme use (200, 400 and $600 \mathrm{ppm}$ ). Comparing the total collection using $\mathrm{Lipe}^{\mathbb{B}}$ and $\mathrm{Cr}_{2} \mathrm{O}_{3}$, a correlation was observed only for the PC results, that were always higher, and for the NC results, that were lower for the three methodologies. For IDE (ileal digestible energy), determined by $\mathrm{Cr}_{2} \mathrm{O}_{3}$, significant differences were observed $(\mathrm{P}<0.05)$ and it presented higher values in the PC treatment and lower values in the NC. In IDE determining by Lipe ${ }^{\circledR}$, significant effect was observed $(\mathrm{P}<0.05)$, showing higher value in the PC treatment. It is concluded that in the metabolism assessments, exogenous alpha-amylase tested was effective in increasing the metabolizable energy (ME), however, not enough to be equivalent to the ME of PC treatment, a result that was better expressed in the total collection, AMEn by Lipe ${ }^{\circledR}$ and IDE by Lipe ${ }^{\circledR}$ methodologies. The performance results reflect the superiority of PC treatment, pointing enzyme limitation to supply the energy deficit practiced in this work.

Key words: Lipe ${ }^{\circledR}$, chromic oxide, metabolizable energy, digestible energy. 